\title{
Regulatory Methods for Sustainable Development Planning of Urban Areas: Perspectives for the Development of National Standards
}

\author{
Petr I. Burak 1*[ORCID 0000-0003-0709-2449], \\ Tatiana I. Zvorikina 1[ORCID 0000-0002-0740-517X], \\ Algirdas Yu. Maniushis 2[ORCID 0000-0003-4506-3104], \\ Marina M. Novikova 3[ORCID 0000-0003-0656-9188], \\ Marina N. Voit 3[ORCID 0000-0003-1023-5156]
}

${ }^{1}$ Institute of Regional Economic Research, Moscow, Russia

${ }^{2}$ Moscow International University, Moscow, Russia

${ }^{3}$ Russian New University, Moscow, Russia

petr-burak@yandex.ru

\begin{abstract}
The article presents the results of research on the application of normative methods of planning sustainable development of urban agglomerations. The key planning method among such as: scenario methods; multifactor models; Delphi method; collective survey; predictive graph; extrapolation method; normative method; individual expert survey is recognized as a normative planning method based on standardization. The importance of urban agglomerations in the formation of the regional economy is shown, the role of standardization in the strategic planning of the development of both regional and sectoral systems is indicated. It is noted that the sustainable development of urban agglomerations depends on the use of standardization tools. The organizational mechanism of standardization of sustainable development, used as a way of planning and forecasting socioeconomic development of territories, is described. A model of regulatory regulation of standardization of sustainable development is proposed based on the need to implement the 17 Sustainable Development Goals adopted by the United Nations and achieve the national development goals defined in the Decree of the President of the Russian Federation (2020). In addition, the publication of new international standards, as well as an analysis of the long-term and medium-term benefits of standardization of sustainable development became the basis for the formation of regulatory regulation of sustainable development. The publication notes that the studies conducted in the field of sustainable development assessment systems adopted in Russian cities indicate the need to adjust the provisions of the current GOST R ISO 37120-2020. In order to clarify the content of the standard, the article formulates specific proposals to expand the composition of indicators for its two sections. In addition, proposals are given for planning the standardization of sustainable development for the coming years, aimed at rationing and evaluating the innovation and production activity of industrial enterprises. In conclusion, it is concluded that standardization can be considered as one of the main methods of innovative development of urban agglomeration.
\end{abstract}

Keywords: normative methods of planning, standardization, sustainable development, urban agglomeration, innovation, forecasting

\section{INTRODUCTION}

Recently, the population of urban agglomerations has been increasing. Agglomeration, in accordance with the draft law on agglomerations, is considered as the territory of an urban district or an urban district with intracity division, or a city of federal significance, united with the territories of other 
municipalities by stable social and economic ties.

The future of generations depends on the sustainable development of both urban agglomerations and administrative-territorial formations and large cities (hereinafter - large cities), namely, the success of the Russian economy, stability of social development and environmental well-being.

Now in Russia, more than $59 \%$ of citizens live in large cities. By 2025, urbanization is projected to increase this figure to $70 \%$. The largest city in Russia is its main city - Moscow, whose population, according to Rosstat, is 12655 thousand people (2021). The population density is 4941.45 people $/ \mathrm{km}^{2}$ (2021). The second city in terms of the number of inhabitants is St. Petersburg, its population is 5384 thousand people (2021). The population density is 3837.73 people $/ \mathrm{km}^{2}$ (2021). The third is the city of Novosibirsk with a population of 1620 thousand people (2021) [1] According to the United Nations (hereinafter - UN), by $2050,70 \%$ of the world's population will live in cities. Industry is concentrated, first, in cities, in which about $40 \%$ of the population is employed. The total number of cities in Russia is 171 , with a population of more than 100 thousand people, 15 cities of which have a population of more than 1 million people, 22 cities have a population of 500 thousand to 1 million inhabitants.

In order to find ways to ensure the sustainable development of large cities, various methods of planning and forecasting socio-economic development are used, among them: scenario methods; multivariate models; Delphi method; collective survey; forecast graph; extrapolation method; normative method; individual expert survey.

The normative planning method based on standardization is recognized as one of the effective planning methods. Standardization is seen as the activity of setting rules, norms, and characteristics for the purpose of their voluntary and repeated use, aimed at streamlining activities. In Russia, the Federal Law of June 29, 2015, No. 165-FZ "On standardization in the Russian Federation" has been adopted and is being implemented. One of the organizational mechanisms for the application of standardization for planning and forecasting sustainable development are technical committees for standardization formed at the international and national levels $[2,3]$. The technical committees for standardization on a voluntary basis include countries and organizations interested in the formation of a regulatory framework.

Russian scientists have taken an active position in the application of standardization as a method of normative regulation of sustainable development of large cities, and since 2013 they have been conducting research on the formation of indicators of sustainable development within the framework of the domestic technical committee for standardization created by Rosstandart TC 115 "Sustainable Development of Administrative Territorial Entities" [2].

Work on the application of planning and forecasting methods has led to tangible results. Six national standards have been developed and applied at the national level, and more than thirty at the international level.

Let us consider the process of applying the method of normative planning of large cities based on mechanisms and standardization tools.

\section{MATERIAL AND METHODS}

When searching for ways to apply a normative planning method based on standardization, general scientific and specific subject research methods were applied.

The scientific approach to research included content analysis of specialized scientific publications, literary sources, the study of research by foreign scientists-specialists in the field of planning, forecasting, sustainable development, as well as in the field of international and national standardization. Strategic planning documents, legal framework, existing national projects, roadmaps containing provisions in the field of application of standardization in planning in various fields of activity were studied, analyzed, and summarized. This approach made it possible to crystallize knowledge and features of the application of standardization both for the innovative development of large cities and for various sectoral areas: industry, transport, small business, services, etc.

The research also used methods of expert evaluations and sociological surveys in order to clarify and adjust the proposed conclusions about the feasibility of standardization.

Analysis of evidence and information on the forms and methods of using standardization tools convinced the authors of the possibility of achieving sustainable development based on their application. 


\section{RESULTS}

The study of the possibility of applying normative methods for planning sustainable development began with studying the theoretical and practical foundations for understanding sustainable development of territories.

For the first time, the conceptual apparatus in the field of sustainable development was discussed in 1987 at the International Commission on Environment and Development, created at the UN General Assembly. At the assembly, the following definition was formulated: "Sustainable development is the development that meets the needs of the present but does not jeopardize the ability of future generations to meet their own needs" $[1,4]$.

Material conditions and living standards are key aspects of ensuring the safety and quality of life in the regions. According to European studies, $47 \%$ of the respondents from the European Union countries called "a good standard of quality of life" as the most important component of their quality of life, and $46 \%$ called it simply important.

Theoretical and practical aspects of the formation of normative regulation and standardization of sustainable development of administrative-territorial entities are considered at the international and Russian levels. Russia, being a member of the World Trade Organization (WTO) and the International Organization for Standardization (ISO), harmonizes its activities with the world community. Considerable attention is paid to the issues of sustainable development of administrative-territorial entities based on the application of international norms. The leading role in the organization of scientific research is taken by the World Bank. Its main interest is the informed choice of sustainable territories for productive investments. On its initiative and support, Canadian scientists conducted studies to substantiate indicators of sustainable urban development. As a result of the development in 2013, ISO was proposed to form an international technical committee ISO/TC 268. It included representatives of TEST St. Petersburg and the Institute for Regional Economic Research (IREI) [4] from Russia. The focus of research conducted at the international level is the substantiation of norms for assessing the sustainable development of territories and the choice of forms, methods and mechanisms for their successful development and improving the quality of life of the population.

It should be noted that at the international level, projects were developed to form indicators and indices of sustainable development. The following international works are among them: World Bank indicators, indicators proposed by the UN Commission on Sustainable Development, OECD environmental indicators, etc.

In Russia, the problem of sustainable development regulation has been studied by such structures as the Center for Environmental Policy of Russia (environmental aspects of sustainable development), IREI (issues of standardization of sustainable development), TEST St. Petersburg (issues of synchronization of the Russian national system of standards with the international), Lomonosov Moscow State University, National Research University Higher School of Economics (issues of sustainable urban development). The largest corporations of the country, responsible for ensuring the sustainable development of the respective types of production, periodically inform the public on this issue.

Sustainable development issues have been discussed [5, 6]. Recent events in the country and around the world are the result of major challenges of our time, such as: developing technological progress, the use of breakthrough technologies, sustainable development, social progress, the occurrence of various disasters (fires, pandemics, floods, etc.), uneven development of territories, social progress. The policy of the state and the choice of strategy are aimed at overcoming the challenges of the global economy, both in relation to the development of all regions and large cities $[1,6]$.

An integrated approach to the formation of a national system of regulation and standardization of sustainable development of regions was outlined in the last 2017-2021.

Studies have shown that standardization is becoming a developing mechanism for the innovative development of the economy. The action plan ("road map") for the Development of Standardization until 2027 includes the use of forms, methods and mechanisms of standardization in: improving legislation (electronic environment, copyright, Code of Administrative Offenses); international and interregional cooperation; development of standardization infrastructure; personnel training and retraining; government partnership, cooperation with business; popularization; improving the functioning of standardization of defense products, as well as with resource support of work. Analysis of strategic planning documents of state development programs 
suggests that 5 out of 41 programs related to solving the problems of forming an information society, developing the transport system, using natural resources, developing agriculture and energy, creating conditions for ensuring public order and fighting crime contain measures for the application of standardization.

5 National Projects out of 12: "Digital Economy of the Russian Federation"; "Housing and Urban Environment"; "Safe and high-quality roads"; "Ecology"; "International cooperation and export" also contain forms of application of standardization in their implementation.

Sections and measures for standardization contain 5 of 7 sectoral, national, and inter-sectoral development strategies until 2025-2035, these are development strategies: tourism, mechanical engineering, the grain complex, export of services.

Analysis of sectoral planning documents (roadmaps) also indicates the important role of standardization in the innovative development of the economy using standardization tools. These are road maps for the following: improving legislation to ensure the implementation of national technological and initiatives in the following areas: "Technet", "Avtonet", "Marinet" for the development of the petrochemical complex in the Russian Federation; for the development of the aluminum industry, as well as for the amber industry of the Russian Federation for the period up to 2025.

Thus, it is possible to conclude that standardization is present as an effective driver for the development of various fields of activity and ensuring sustainable development of territories.

\section{DISCUSSION}

Many scientists in the field of sustainable development of territories express their vision of this phenomenon [2, 4]. In their opinion, sustainable development can be understood as a component of not three, but four components (Figure 1), including additionally one more group of indicators - energy.

Based on the nature of standardization and its potential for standardizing the development of an agglomeration or a large city, it is possible to foresee long-term economic benefits from its application. First, this is a significant reduction in the time for introducing new products and technologies sold in the city using already developed standard (best) practices and technologies. Secondly, standardization will be able to facilitate the implementation of innovative solutions in various fields of activity.

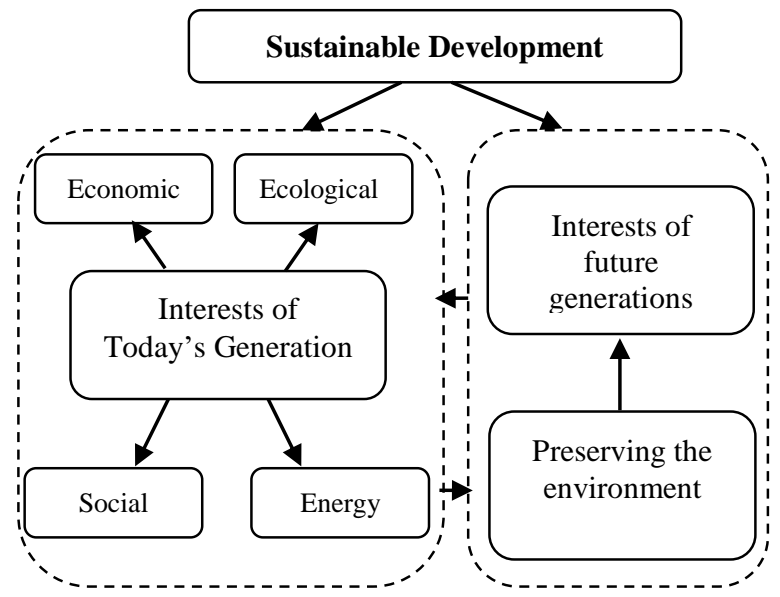

Figure 1. Modern understanding of the sustainable development of the agglomeration

Source: [4]

In addition, standardization and streamlining activities will affect the development of small and medium-sized businesses (by offering proven solutions, increasing confidence in the products of small enterprises, improving the culture of production and the quality of products and services). Due to standardization, it is possible to eliminate market defects based on the rationing of important indicators, including environmental ones, labor protection requirements, product labeling, etc. (improving the quality of life) [7].

By standardizing the requirements for the personnel of organizations and the application of professional standards, it is possible to ensure a constant growth in the qualifications of the personnel. Thus, the use of regulatory planning methods based on standardization will make it possible to achieve a long-term stable position in the domestic and foreign markets.

These methods also have medium-term economic benefits. So it is possible to achieve a reduction in the cost of products manufactured in the city based on the simplification of production processes through the use of interoperability. It is also possible to influence the development of competition within a large city, when new techniques and technologies are introduced through the standard as a conductor. Through the standard, the city's products can be promoted to global markets by harmonizing standards with the latest ISO/IEC standards and participating in international certification schemes. 
At the international level, as noted above, the standards governing indicators and indicators of sustainable urban development ISO 37120:2018, ISO 37122:2019 and ISO 37122:2019 have been adopted. In Russia, work is underway to adapt them to domestic conditions. The first standard has been translated and applied in Russia as a national one. Two other international standards that characterize the requirements for smart and resilient cities are included in the PNS for 2021-2022 to adapt them as national.

The need to implement the 17 sustainable development goals adopted by the UN and achieve the national development goals defined in the Decree of the President of the Russian Federation (2020), the publication of new international standards, as well as the analysis of the long-term and medium-term benefits of sustainable development standardization allow us to propose a model of normative regulation of sustainable development standardization which can be formulated as follows:

"The model of the national system for the regulation and standardization of sustainable development of an agglomeration (including a large city) is a set of documents that regulate the requirements for sustainable development at the national, regional and local levels establishing the rules and shaping directions for ensuring economic growth, environmental and social development, and resource conservation, the organizational structure of the participants and the rules for the functioning of the system as a whole".

In Russia, on August 1, 2021, the second version of GOST R ISO 37120-2020 was introduced, which contains methods for applying a set of basic and additional indicators of sustainable development that ensure the management and measurement of the efficiency of urban services and the quality of life. The object of standardization of this standard is indicators of urban services and quality of life, which regulate the following elements: economy, education, energy, environment, finance, management, health care, housing, population and social conditions, recreation, unemployment, solid waste, sports and culture, telecommunications, transport, urban and peri-urban agriculture, food security, urban planning, wastewater, water. In addition, the standard contains requirements for reporting and accounting.

The applied standard repeats the provisions of the international standard. However, its content is controversial. Some researchers in the field of sustainable development believe that it is necessary to adapt the provisions and indicators of the current standard to the realities of Russian reality [10].

The studies carried out in the field of sustainable development assessment systems adopted in Russian cities (primarily in industrial cities) indicate the need to adjust the provisions of the standard. Based on the analysis, it was concluded that several sections of GOST R ISO 37120-2020 require correction and clarification.

Table 1 and Table 2 give specific proposals for a revised and expanded composition of indicators for two sections of the standard, objectively reflecting the indicators of a large city and the quality of life of the population in it. After public discussion, these indicators can be included in a modified version of GOST R ISO 37120-2020 and will allow an objective assessment of the sustainable development of any city.

Table 1. Supplement of the GOST R ISO 37120-2020 standard with new indicators in terms of social security of the urban population of a large city

\begin{tabular}{|l|ll|}
\hline \multicolumn{1}{|c|}{$\begin{array}{c}\text { Title of the Section of the } \\
\text { Standard and its Number }\end{array}$} & & \multicolumn{1}{c|}{ Innotive Proposal for Expanding Indicators } \\
\hline & - & the total area of residential premises, on average per one city dweller (m2) \\
& - & commissioning of residential buildings (thousand m2 of total area) \\
& - & the proportion of residential buildings in emergency condition \\
& - & the proportion of residential buildings requiring current repair \\
Housing provision & - & the proportion of public buildings requiring current repair \\
(Comfort when living in an & - & the proportion of buildings equipped with smart electricity meters \\
administrative-territorial unit) & - & the proportion of residential premises equipped with smart water meters) \\
(number 12) & - quality of work of housing and communal services \\
& - the quality of roads and the availability of parking \\
& - noise level \\
\hline Providing employment for the & - capacity of the urban energy system per capita (GJ/person) \\
& - the number of organizations registered in the administrative-territorial unit (at the end \\
\hline
\end{tabular}




\begin{tabular}{|c|c|}
\hline $\begin{array}{l}\text { Title of the Section of the } \\
\text { Standard and its Number }\end{array}$ & Innovative Proposal for Expanding Indicators \\
\hline $\begin{array}{l}\text { local population (Opportunity } \\
\text { to apply professional skills and } \\
\text { increase welfare) (number 13) }\end{array}$ & $\begin{array}{l}\text { of the year) } \\
\text { - the percentage of the population employed in organizations (at enterprises, in } \\
\text { institutions) of the administrative-territorial unit }\end{array}$ \\
\hline Education (number 6) & $\begin{array}{l}-\quad \text { the proportion of university graduates who got a job after graduation in their specialty } \\
-\quad \text { the share of graduates who went abroad } \\
-\quad \text { the percentage of the salary of graduates to the average for the region }\end{array}$ \\
\hline
\end{tabular}

Source: [4]

Table 2. Supplementing the standard with new indicators in terms of ensuring conditions for the leadership and development of the economy of a large city

\begin{tabular}{|c|c|}
\hline $\begin{array}{l}\text { Title of the Section of the } \\
\text { Standard and its Number }\end{array}$ & Innovative Proposal for Expanding Indicators \\
\hline Leadership (number 10) & $\begin{array}{l}\text { - the number of state (municipal) employees per } 10,000 \text { people of population } \\
\text { - } \\
\text { the share of public administration initiatives based on citizens' appeals of the total } \\
\text { number of initiatives } \\
\text { - } \text { the proportion of the population with access to online services of enterprises and } \\
\text { organizations that provide state and municipal services } \\
\text { - the share of the municipal budget allocated to the creation of an accessible } \\
\text { environment for persons with disabilities (provision of vehicles, lifting devices, auxiliary } \\
\text { equipment, etc.) }\end{array}$ \\
\hline $\begin{array}{l}\text { Socio-economic development } \\
\text { of the administrative-territorial } \\
\text { unit (number } 5 \text { ) }\end{array}$ & $\begin{array}{l}\text { - the volume of self-produced goods, works and services per } 1 \text { inhabitant } \\
-\quad \text { the average monthly nominal accrued wages } \\
-\quad \text { the ratio of the cost and quality of life (income sufficiency to cover all mandatory } \\
\text { expenses and comfortable living) } \\
\text { - the payback period of investments in residential real estate }\end{array}$ \\
\hline $\begin{array}{l}\text { Consumer market } \\
\text { development (number 5) }\end{array}$ & $\begin{array}{l}\text { - the retail trade turnover per inhabitant on average } \\
\text { - } \text { the walking distance of outlets (shops) providing products and essential goods of } \\
\text { proper quality } \\
\text { - } \text { the proportion of the population with access to online services of enterprises and } \\
\text { organizations providing consumer services (ordering a taxi, online booking, calling a } \\
\text { specialist at home, delivery, etc.) }\end{array}$ \\
\hline
\end{tabular}

Thus, the studies carried out in terms of finding ways to objectively assess and regulate the sustainable development of large cities allow us to conclude that it is necessary to adjust and clarify a few indicators of sustainable development given in the standards in order to increase the effectiveness of the application of the normative method of planning the development of a large city.

Proposals for the development of the application of regulatory planning methods

Objective reality suggests that metropolitan areas (including large cities) are faced with a few challenges (problems). Their sustainable development largely depends on the innovation and production activity of industrial enterprises located within a large city [8, 9].

Industrial enterprises, as noted above, are located mainly in large cities and make a significant contribution to GDP. In addition, they represent an important potential for ensuring the quality of life of the population. It is possible to judge the industrial resource of the region and the reliability of investing in it both budgetary and commercial funds by innovative and industrial activity [10].
Despite the importance of assessing innovation and industrial activity, as studies have shown, there is still no scientifically grounded methodology for assessing it, which makes it possible to objectively and uniformly make a choice of a promising, reliable and active industrial enterprise. Russian and foreign experts offer many different systems and assessment criteria, which complicates comparative analytical work within large territories and long time periods. The task is to introduce uniformity in the methodology for assessing the innovative and industrial activity of industrial enterprises and to develop a set of scientific, methodological and organizational and technical measures to intensify their activities. It is necessary to substantiate the priority indicators and indicators of the activity of enterprises based on large-scale scientific research, which provide the starting conditions for the innovative development of a large city, and to develop sectoral mechanisms and tools to accelerate the development of industrial enterprises within the city. Experts in the field of assessing innovation and production activity proposed to include the development of two standards in the national standardization plan. The rationale for the development is given in the Table 3. 
Table 3. Motivated rationale for the prospect of developing new standards

\begin{tabular}{|c|c|c|c|}
\hline $\begin{array}{l}\text { Organization } \\
\text { Responsible } \\
\text { for the } \\
\text { Development }\end{array}$ & $\begin{array}{c}\text { Name of the } \\
\text { Draft } \\
\text { Document }\end{array}$ & $\begin{array}{l}\text { Preparation } \\
\text { of the First } \\
\text { Edition of } \\
\text { the Project }\end{array}$ & $\begin{array}{l}\text { Detailed Motivated Justification of the Feasibility of Developing, } \\
\text { Updating the Standard and a Brief Description of the Object and } \\
\text { Aspect of Standardization }\end{array}$ \\
\hline $\begin{array}{l}\text { IREI, } \\
\text { Moscow City } \\
\text { Duma }\end{array}$ & $\begin{array}{c}\text { Sustainable } \\
\text { development } \\
\text { of } \\
\text { communities. } \\
\text { Indicators of } \\
\text { innovation } \\
\text { and } \\
\text { production } \\
\text { activity of } \\
\text { industrial } \\
\text { enterprises }\end{array}$ & $\begin{array}{l}\text { Development } \\
\text { of a national } \\
\text { standard } \\
\text { (GOST R) } \\
\text { September } \\
2022\end{array}$ & $\begin{array}{l}\text { Sustainable development of the territory largely depends on the innovation } \\
\text { and production activity of industrial enterprises located within the region. } \\
\text { These enterprises make a huge contribution to GDP and represent a } \\
\text { significant potential for ensuring the quality of life of the population of the } \\
\text { territory. By innovative and industrial activity, it is possible to judge the } \\
\text { industrial resource of the region and the reliability of investment of both } \\
\text { budgetary and commercial funds. In this regard, the problem arises of } \\
\text { formalizing indicators of innovation and production activity of industrial } \\
\text { enterprises. Their standardization will make it possible to develop a single } \\
\text { technical language in assessing activity and to approach unambiguously } \\
\text { the choice of prosperous enterprises, the adoption of effective management } \\
\text { decisions by the authorities and local self-government, and the } \\
\text { development of a regional development strategy. The legal basis for the } \\
\text { preparation of the national standard can be the Strategy for Innovative } \\
\text { Development dated } 06.03 .2021 \text { of the Ministry of Science and Education }\end{array}$ \\
\hline $\begin{array}{l}\text { IREI, } \\
\text { Moscow City } \\
\text { Duma }\end{array}$ & $\begin{array}{c}\begin{array}{c}\text { Sustainable } \\
\text { development } \\
\text { of }\end{array} \\
\text { communities. } \\
\text { Assessment } \\
\text { of innovation } \\
\text { and } \\
\text { production } \\
\text { activity of } \\
\text { industrial } \\
\text { enterprises }\end{array}$ & $\begin{array}{l}\text { Development } \\
\text { of a national } \\
\text { standard } \\
\text { (GOST R) } \\
\text { October } \\
2022\end{array}$ & $\begin{array}{l}\text { Industrial enterprises make a significant contribution to GDP, create jobs, } \\
\text { and ensure stable and sustainable development of the teritory. } \\
\text { Assessment of the innovative and production activity of industrial } \\
\text { enterprises is becoming extremely important in the face of modern } \\
\text { challenges of the time. Currently, in Russia and abroad, there are several } \\
\text { methods for assessing the activity of enterprises, but there is no single } \\
\text { approach. In connection with the need for an objective understanding of the } \\
\text { innovation and production activity of enterprises, a national standard is } \\
\text { needed. The standard will make it possible to solve the following tasks: } \\
\text { - carry out constant monitoring of the dynamics of innovation and } \\
\text { production activity of industrial enterprises; } \\
\text { - form strategies for the development of industry based on the information } \\
\text { received; } \\
\text { - choose enterprises to present preferences; } \\
\text { An objective assessment will be based on available indicators officially } \\
\text { presented in open sources of information. The assessment will be carried } \\
\text { out according to an objective, transparent, standardized methodology and } \\
\text { characterize convincingly the production and innovation activity of industrial } \\
\text { organizations. } \\
\text { The standard is developed on the basis and considering the current } \\
\text { regulatory documents governing the requirements for the strategic } \\
\text { development of the territory. }\end{array}$ \\
\hline
\end{tabular}

Source: Compiled by the authors

The further use of a normative planning method based on standardization will make it possible to apply this tool to achieve sustainable development. Unification, formalization and standardization of indicators of innovation and production activity will make it possible to solve the following tasks:

- carry out constant monitoring of the dynamics of innovation and production activity of industrial enterprises in the city;

- form strategies for the development of urban industry based on the information received;

- select enterprises to represent various forms of support and establish preferences in a large city.

The proposed development will become one of the elements in the set of standards for sustainable development.

\section{CONCLUSION}

Currently, it is necessary to search for ways and mechanisms to implement the $17 \mathrm{UN}$ sustainable development goals and national goals (Presidential Decree 2020). The primary task is to create the theoretical and methodological foundations for ensuring the sustainable development of a large city and the quality of life. A normative method for planning and forecasting the development of a large city (including an agglomeration) based on standardization can be such an effective tool. Determination and development of directions, methods and organizational and economic measures of normative regulation of the sustainability of cities becomes important.

The studies carried out in terms of finding ways to assess and regulate the sustainable development 
of large cities objectively allow us to conclude that:

- standardization at the national level becomes an effective tool in achieving the goals of urban development in terms of economic development, achieving environmental wellbeing and social improvement and resource conservation;

- in the new version of the international standard, a wide sector of indicators is presented, however, an analysis of the state of solution of issues of economy, ecology, social improvement and resource conservation gives grounds to suggest that a whole range of innovations that reflect the real state of affairs must be introduced into the modernized version of the national standard for sustainable development in industrial cities, however, it requires adjustment.

It is advisable to propose the development of two national standards and include them in the PNS for the next two years as promising developments in terms of theoretical foundations for the formation of indicators of innovative and production activity of industrial enterprises of a large city, methodology for their assessment and standardization in order to ensure sustainable development of communities (regions).

\section{AUTHOR'S CONTRIBUTION}

Petr I. Burak - general project management, analysis and addition of the text of the article. Tatiana I. Zvorikina - systematization and generalization of research materials, preparation of recommendations for the development of sustainable development standardization. Algirdas Y. Maniushis - forming proposals for assessing the innovative and production activity of industrial enterprises. Marina M. Novikova - collection and processing of materials, preparation of the initial version of the text. Marina N. Voit - preparation and justification of the modernized version of GOST R ISO 371202020 .

\section{ACKNOWLEDGMENTS}

The article was prepared with the financial support of the Russian Foundation for Basic Research, project № 20-010-00343

\section{REFERENCES}

[1] D.M. Zhuravlev, "Development and formation of a model for managing innovative development of a subject of the Russian Federation", Bulletin NGIEI, 2020, vol. 10(113), pp. 86-97. (In Russ.). DOI: 10.24411/2227-9407-2020-10097

[2] P.I. Burak, T.I. Zvorykina, S.M. Magomedov, A.V. Nosov, S.P. Fomina, "Indicators and indices of sustainable development of administrative-territorial entities, selection of priority objects of standardization", International Journal of Economic Research, 2017, vol. 14(15), pp. 417-428.

[3] V.G. Rostanets, T.I. Zvorykina, A.V. Topilin, A.I. Kabalinskii, I.S. Androshina, "Standardization of interregional economic relationships as a tool for fostering integration processes in the Russian economy", The Journal of Social Sciences Research, 2018, vol. 3, pp. 283-290. DOI: 10.32861/jssr.spi3.283.290

[4] T.I. Zvorykina, T.V. Kharitonova, E.A. Kudryavtseva, "The model of the fundamental innovative national standard forming the system of indicators and indicators of sustainable development of territories", Information and Economic Aspects of Standardization and Technical Regulation, 2019, vol. 4(50), p. 10. (In Russ.).

[5] S. Brorström, "The Strategy Process as a Result of Learning, Questioning, and Performing in a City Organization", International Public Management Journal, 2020, vol. 23(4), pp. 1-25. DOI: $10.1080 / 10967494.2019 .1606127$

[6] I.M. Bamatov, E.V. Alekseev, A.A. Silaeva, A.L. Faizrakhmanova, A.V. Melnichuk, T.I. Zvorykina, "Industrial Waste Disposal: Development of New Technologies and Economic Mechanisms of Management", International Journal of Recent Technology and Engineering, 2019, vol. 8(3), pp. 7944-7949. DOI: 10.35940/ijrte.C6634.098319

[7] F. Sussan, Z.J. Acs, "The digital entrepreneurial ecosystem", Small Business Economics, 2017, vol. 49(5), pp. 55-73. DOI: 10.1007/S11187017-9867-5

[8] P. Cohendet, D. Grandadam, L. Simon, "The Anatomy of the Creative City", Industry and 
Innovation, 2010, vol. 17, pp. 91-111. DOI: $10.1080 / 13662710903573869$

[9] K.S. Al-Omoush, V. Simon-Moya, M.A. Alma'aitah, J. Sendra-Garcia, "The determinants of social CRM entrepreneurship: An institutional perspective", Journal of Business Research, 2017, vol. 132, pp. 21-31. DOI:

\subsection{6/J.JBUSRES.2021.04.017}

[10]K. Tomičić-Pupek, I. Pihir, M. Tomičić Furjan, "Smart city initiatives in the context of digital transformation - scope, services and technologies", Journal of Contemporary Management Issues, 2019, vol. 58, pp. 39-54. DOI: $10.30924 / \mathrm{mjcmi} .24 .1 .3$ 